\title{
CONDICIONAMENTO SÓCIO-CULTURAL DAS ORIGENS DO MOVIMENTO UNIVERSITÁRIO EUROPEU: A SINGULARIDADE DO CASO PORTUGUÊS (V).
}

(Continuação) .

\author{
ALDO JANOTTI \\ do Departamento de História da Faculdade de Filoso- \\ fia, Letras e Ciências Humanas da Universidade de \\ São Paulo.
}

CAPITULO II.

\section{HOUVE CONDICÕES PARA O NASCIMENTO DA UNIVERSIDADE PORTUGUESA?}

B). -O ARCAISMO SOCIAL.

$\mathrm{Na}$ explicação dos fundamentos da Universidade européia, tivemos a oportunidade de relacioná-los com a atuação concomitante de condições de dupla natureza: sociais e culturais. As primeiras foram originadas pelo renascimento urbano do século XII, enquanto que as segundas pelo renascimento cultural daquela mesma época. E muito natural que agora, ao pretendermos explicar as origens da Universidade portuguêsa, façamos uma sondagem no sentido de verificar se aquelas mesmas condições que atuaram no aspecto mais geral do movimento universitário medieval, isto é, europeu, também atuaram no seu aspecto mais particular, ou seja, português.

Se estabelecermos um paralelo entre as condições sociais da Europa, nos fins do século XII, quando se iniciou então, como consequiência de condições favoráveis, o seu movimento universitário e as condi- 
ções sociais de Portugal, nos fins do século XIII - com a diferença, portanto, de um século - e quando também se originou, fundada por D. Denis, a sua Universidade, chegaremos à conclusão, levados pela evidência das discrepâncias, que Portugal, não tendo acompanhado o rítmo evolutivo da história européia, se apresentava como um país socialmente anacrônico. A Europa, transformada nos seus fundamentos econômicos pelo renascimento do comércio que propiciou o renascimento das cidades, ao mesmo tempo em que perdia os característicos, quase que, exclusivamente rurais que dominavam a sua estrutura sócio-econômica, adquiria os novos característicos de uma nova estrutura. Surge a economia urbana - cujos primeiros lineamentos já podem ser surpreendidos desde os fins do século XI — e que conhecerá o seu apogeu nos fins do século XIII (51). Surge também uma nova classe social, a burguesia, pois o aparecimento das cidades modificou, profundamente, o estado social da Europa (52). Enfim, surge uma nova Europa, a Europa que se urbaniza (53). Mas isto tudo se passou, na Europa, e em Portugal; o que aconteceu? País demasiadamente periférico, resultado do seu ocidental extremismo geográfico, Portugal como que saiu da órbita de atração do sistema histórico europeu, não evoluindo assim, e por consequiência, no mesmo rítmo da Europa. E a lentidão que vai passar a caracterizar as transformações da história portuguêsa, contrapondo-se ao peculiar dinamismo das transformações européias, explica-nos, porque, cada vez mais, deixa de haver sincronismo histórico entre Portugal e a Europa. Daí o anacronismo, o anacronismo português. E por isso que, enquanto o sistema histórico europeu se deixava, completamente, renovar pelas poderosas influências do urbanismo, Portugal - desgarrado do sistema - insistentemente conservador, continuava comprometido com a arcaica e arcaizadora influência do agrarismo. Sua vida econômica era tìpicamente rural (54). E sua vida social se caracterizava com a de um país que

(51). - Pirenne, Renaudet, Perroy e outros, La fin du Moyen Age La désagregation du monde médiéval (1285-1453), Paris, Librairie Félix Alcan, 1931, p. 17.

(52). - Pirenne, Histoire de l'Europe, p. 176.

(53). - "On peut donc dire qu'à partir de l'apparition des villes et de la formation de la bourgueosie, on se trouve en présence d'une Europe nouvelle. Toute la vie sociale est transformée: la population doublée, la liberté se généralise, le commerce et l'industrie, la circulation de l'argent, le travail de l'esprit se font une place de plus en plus grande et donnent de nouvelles possibilités au développement de l'État et de la Societé". (Pirenne, op. cit., p. 179).

(54). - "Até a época dos descobrimentos a agricultura é o fundamento econômico da nação", Lúcio Azevedo, O período agrário, in "História de Portugal", ed. Monumental, v. II, p. 406; "Nos primeiros tempos da monarquia era a agricultura quase a única fónte de riqueza pública, e mesmo essa sofria, principalmente nas terras do sul, as conseqüências de incessantes guerras com 
"era na realidade a sede de uma associação vasta de lavradores" (55).

A constatação dêsse anacronismo social se nos afigura de importância excepcional, sempre que se pretender interpretar as diferentes manifestações da história medieval portuguêsa. No campo intelectual veremos - no devido tempo - que êle também se fará notar ao imprimir características próprias à cultura portuguêsa que, apoiada num background social anacrônico, não estará em condições de acompanhar a cadência rítmica da evolução da cultura européia. Assim, não deverá causar estranheza, se, quando tratarmos das origens da Universidade portuguêsa, não encontrarmos aquilo que já encontramos, nas origens do movimento universitário europeu, ou seja, o renascimento urbano, como condição responsável pela solidariedade que ligou a evolução da vida cultural às transformações da vida social, comandadas uma e outra pela revolução do regime econômico, conforme nos referimos no capítulo anterior, apoiados em Paré, Brunet e Tremblay. A revolução do regime econômico se iniciou com o renascimento do comércio e continuou com o renascimento urbano; e êste, efeito e, ao mesmo tempo, causa da referida evolução econômica se constituiu na condição da solidariedade do social com o cultural. Nessa solidariedade é que as universidades européias encontraram os fatôres que condicionaram o seu aparecimento. Essa solidariedade foi de natureza revolucionária. Até então era o agrarismo o elo da solidariedade entre o social (feudalismo) e o intelectual (idade beneditina); agora, com a revolução urbana que, como já observamos, transformou, por completo, o panorama histórico da Europa ocidental, será o urbanismo o nôvo e revolucionário elemento que irá solidarizar duas revoluções, a social (renascimento urbano) e a intelectual (renascimento do século XII). Como uma verdadeira revolução pedagógica, o nascimento das Universidades do Ocidente será uma das expressões dessa solidariedade. Em Portugal não houve renascimento urbano, continuando assim a sua história a ser caracterizada pelas diferentes manifestações que se originavam de uma fonte comum, o agrarismo. A origem da Universidade portuguêsa irá ressentir-se daquela ausência de condição social que, no entanto, tão presente estêve nas origens da Universidade européia.

os mouros", Fortunato de Almeida, op. cit., v. I, p. 444; "Nos primeiros séculos da existência de Portugal, a agricultura domina a vida da Nação; e tão profundamente, que até a população dos maiores centros urbanos vivia em grande parte da exploração agrícola, embora a devamos supor associada a outras formas de atividade". (Damião Peres, $A$ atividade agricola em Portugal nos séculos XII a XIV, in "Congresso do Mundo Português"; Lisboa, 1940, v. II, p. 465).

(55). - Lúcio Azevedo, Epocas de Portugal Econômico, Lisboa, Livraria Clássica Editôra, 1929 , p. 31 . 
A ausência de renascimento urbano em Portugal - entendida a expressão no sentido de extraordinário desenvolvimento da vida urbana e que passou a se constituir no fundamento capital da evolução histórica européia, a partir do século XII — poderá ser fàcilmente justificada, se considerarmos que lá também estêve ausente uma revolução de caráter econômico, sobretudo comercial, e que, de maneira impressionantemente decisiva, comandou os destinos da Europa. Impõe-se, dessa forma, para melhor compreensão dos fatos, uma análise da situação econômica de Portugal às vésperas do nascimento da sua Universidade.

Para que a vida econômica na Idade Média portuguêsa sofresse as transformações que a partir do século XII revolucionaram a vida econômica e, por consequiência, a vida social da Europa, seria necessário que, ao lado da produção agrícola, houvesse uma complementar circulação, não apenas baseada na produção agrícola, mas também, baseada na industrial. No entanto, o comércio português,

"direta ou indiretamente, dependia da exploração do solo" (56), e indústrias, "não havia outras que as de caráter doméstico, indispensáveis, e de mais perto relacionadas com a da terra" (57).

Realmente, comércio existia, na economia agrária portuguêsa da Idade Média, e, é sintomático verificar-se, quando se quer compreender o processo da "europeização" de Portugal que, precisamente a partir dos meados do século XIII, o comércio internacional português conheceu uma intensificação até então nunca vista (58). O movimento comercial da Europa dessa época gravitava em tôrno de duas áreas geográficas distintas: o Mediterrâneo e o Norte (mar do Norte e mar Báltico). Era no Mediterrâneo que continuava a se irradiar o grande comércio que alimentava a indústria das matérias primas e transportava os produtos, ao mesmo tempo, que fornecia à circulação tanto artigos alimentares - sal, trigo, vinho etc. - quanto objetos de luxo (peles, especiarias, tecidos do Oriente) (59). Veneza e Gênova destacavam-se como os entrepostos principais dêsse comércio: e sua rivalidade v. II, p. 466 .

(56) .- Damião Peres, op. cit., in "Congresso do Mundo Português",

(57). - Lúcio Azevedo, op. cit., p. 31.

(58). - "A partir dos meados do século XIII tornam-se importantes as notícias do comércio internacional português, até aí, segundo tôdas as probabilidades, de valor reduzido". (Saraiva, op. cit., v. I, p. 388).

(59). - Pirenne, Renaudet, Perroy e outros, op. cit., p. 19. 
"que se pode comparar, mutatis mutandis, àquela da França e da Inglaterra nos séculos XVII e XVIII, não as impede de desenvolver suas feitorias nas escalas do Levante e de fundar novas. E por sua navegação que o Ocidente se aprovisiona de mercadorias e de produtos orientais, que tomam um lugar, cada vez maior, na existência dos povos europeus. Barcelona e Marselha participam, ao lado delas, dêsse tráfego remunerador" (60).

O mar do Norte e o mar Báltico eram vias de um movimento comercial baseado nos draps da Flandres, vinhos do Reno, madeiras de construção, trigo do norte e peles da Rússia (61). Bruges, na Flandres, não apenas permanecia o principal centro dêsse comércio. como era ainda para o pôrto dela que gravitava a navegação, menos importante da Inglaterra e a cabotagem que os bretões, os gascões e os bascos exerciam nas costas do Atlântico (62).

Entre êsse duplo movimento comercial, o do Mediterrâneo e o do Norte, havia trocas que, no dizer de Heaton, foram um dos grandes aspectos do comércio medieval (63). Essas trocas não se faziam através de um contacto regular pela via marítima (64), pois o mesmo se dava mais pela via terrestre, sobretudo por intermédio da região da Champagne, cujas feiras logo se tornaram como que

$$
\text { "a bôlsa do comércio ítalo-flamengo" (65). }
$$

No entanto, durante as últimas décadas do século XIII, à med da que o contacto pela Champagne ia se tornando cada vez mais difícil, ia se processando, cada vez mais, também, o trafego pela via marítima (66),

\footnotetext{
"no qual a costa portuguêsa era uma obrigatória zona de trânsito" (67).
}

E o comércio marítimo português era estimulado por êsse tráiego (68). Vejamos, apesar das dificuldades, que ainda hoje se nos

(60). - Idem, ibidem, p. 19.

(61). - Idem, ibidem, p. 19.

(62). - Idem, ibidem, p. 19.

(63). - Histoire économique de l'Europe - Des origines à 1750, Paris, Livrairie Armand Colin, 1950, v'. I, p. 137.

(64). - Pirenne, Renaudet, Perroy e outros, op. cit., p. 19.

(65). - Pirenne, Histoire de l'Europe, p. 167.

(66). - Heaton, op. cit., v. I, p. 139-40.

(67). - Saraiva, op. cit., v. I, p. 388.

(68). - Idem, ibidem, v. I, p. 388. 
apresentam (69), o desenvolvimento do comércio externo português, na época, e que os

"progressos da marinha acompanhavam paralelamente" (70).

País de economia tìpicamente rural - num tempo em que a economia urbana chegava ao seu apogeu na Europa (71) - era natural que o comércio externo português estivesse grandemente baseado na agricultura, que o condicionava (72). Ora, durante o reinado de D. Afonso III,

"um dos reis que mais se ocuparam na povoação e restauração das terras do seu reino" (73)

e, sobretudo, durante o de D. Denis, a agricultura alcançou um progresso tal que, em breve,

(69). - "Para seguir até ao seu bêrço a história da marinha, que no futuro devia ilustrar o nome português em todos os mares e nas quatro partes do mundo, as antigas éras só nos legaram fragmentos deficientes; pequenos vestígios de viagens ao fio da costa e de mínimos combates navais; exíguos apontamentos de progressos sucessivos. Os próprios portuguêses desprezaram, até hoje, o investigar, na sua germinação e no seu ulterior desenvolvimento, a glória adquirida no mar. Desprezaram um gôso do espírito, que é. tão natural ao indivíduo nascido no país, ao herdeiro daquela glória e que se lhe torna muito mais fácil e recrativo do que a 0 afastado estrangeiro. Penosamente recolhe êste os apontamentos fortuitos que o cronista deixa aqui e ali, ou as palavras, semi-inteligiveis, de um diploma que foi redigido numa intenção muito diversa; êle larga, assim, o leitor muito menos satisfeito ainda que a própria pesquisa sem resultado deixou o mesmo colecionante pesquisador". (Schaefer, História de Portugal, v. I, p. 271). Poder-se-ia objetar a citação supra de Schaefer: trata-se afinal de historiador do século passado e o que êle escreveu a respeito se correspondia à situação dos estudos históricos portuguêses na sua época, poderia não mais coresponder à realidade da época atual. Somos no entanto obrigados a dizer que Verlinden, moderno historiador belga, e que também se tem ocupado do comércio medieval português, hoje repete a queixa do historiador alemão, confirmando-o. (Cf. Le problème de l'expansion commerciale portugaise au Moyen Age, in "Biblos", Coimbra, Coimbra Editora Limitada, 1947, v. XXIII, t. II).

(70). - Fortunato de Almeida, História de Portugal, Coimbra, Ed. Fortunato de Almeida, 1922, t. I, p. 251.

(71). - Pirenne, Renaudet, Perroy e outros, op. cit., p. 17.

(72) . - "Todo tráfego de Portugal com o estrangeiro tinha por base a agricultura, que ministrava os produtos à exportação, e cujas necessidades os da importação satisfaziam". (J. Lúcio Azevedo, Épocas de Portugal Econômico, p. 31).

(73) . - Fr. Antônio Brandão, Monarquia Lusitana, apud Fortunato de Almeida, op. cit., t. I, p. 222 . 
"a produção dos cereais e de outros frutos da terra excedia o consumo interno" (74).

Havia assim um excedente para a exportação e que foi aproveitado pelos dois monarcas. Com quem, e o que comerciava Portugal? Os navios portuguêses visitavam, regularmente, os portos do mar do Norte e do Mediterrâneo (75). Eram exportados azeite, cêra, cortiça, mel, vinho, peles.

"com intermitências, o que dependia dos anos de fartura e escassês, a cevada e o trigo" (76),

e o sal (77); e eram importados panos, cordões, cintos, objetos de adôrno, especiarias (açafrão e pimenta), talvez, algum cobre e estanho (78), e

\footnotetext{
"armas de melhor lavor e vários artigos de marcenaria mais apurados" (79).
}

Os principais centros do movimento comercial eram Lisboa e Pôrto, ambos bafejados pela sua excelente situação geográfica, pois dominava, cada um, na foz de um grande rio. Mas ainda tinham movimento os portos de Setúbal, Faro, Tavira e, no Além-Douro, o da foz do Lima (80).

D. Afonso III e D. Denis foram os fomentadores dêsse comércio. O primeiro, nesses centros de comércio, mandou construir casas para alugar ou comprou casas já edificadas, que serviram de pousada ou de loja aos mercadores (81); em seu reinado deu-se o aparecimento dos corretores e fretadores profissionais de navios (82); e sustentava frota poderosa, com a qual fêz frente a dos mouros, auxiliou o rei de Castela e, por causa dela, foi convidado pelo papa a prestar o seu auxí-

(74). - Ângelo Ribeiro, Política de fomento nacional, in "História de Portugal", Edição Monumental, v. II, p. 295.

(75). - J. Lúcio Azevedo, Complemento da vida econômica, in História de Portugal, Ed. Monumental, v. II, p. 427.

(76). - J. Lúcio Azevedo, Epocas de Portugal Econômico, p. 17.

(77). - Idem, Complemento da vida econômica, in "História de Portugal", Ed. Monumental, v. II, p. 423.

(78). - Idem, Epocas de Portugal Econômico, p. 21-22.

(79). - Fortunato de Almeida, op. cit., t. I, p. 251.

(80). - Ângelo Ribeiro, op. cit., in História de Portugal, Ed. Monumental, v. II, p. 280 .

(81). - Idem, ibidem, v. II, p. 280.

(82). - Saraiva, op. cit., v. I, p. 389. 
lio na guerra santa (83). No tempo de D. Denis o comércio se desenvolveu ainda mais: comerciantes estrangeiros vieram estabelecer-se em Lisboa, Pôrto, Faro, Setúbal (84); os mercadores do Pôrto instituiram em 1293 um fundo de seguro,

\begin{abstract}
"para ocorrer aos gastos extraordinários a que possam ver-se obrigados os navios da praça em portos estrangeiros. A qüota era obrigatória: maior ou menor, segundo o porte fôsse de cem toneladas e para acima ou abaixo disso. $O$ fato de se mencionarem barcos de mais de cem toneladas, raros na época, é significativo do adiantamento do comércio, e dos progressos das artes náuticas. $O$ ajuste entre os mercadores do Pôrto foi confirmado pelo rei, dizendo êste, no documento respectivo, que o considera muto a serviço de Deus e seu, e a proveito da terra" (85);
\end{abstract}

e, finalmente, preocupou-se o monarca com a marinha real.

Comércio, portanto, houve. Mas o que interessa, não é a pura e simples constatação da existência do comércio, e sim, a análise da natureza do mesmo, a fim de verificarmos, se êle tinha a fôrça necessária ou, pelo menos, suficiente, para estar em condições de proporcionar modificações - e na Europa, elas foram radicais, a ponto de poderem ser consideradas revolucionárias - quer na vida econômica, pròpriamente dita, quer na vida social portuguêsas. Pois bem, foi, precisamente, essa fôrça que faltou ao comércio português, inclusive na época de Afonso III e D. Denis, quando então, e inegàvelmente, êle conheceu progressos. Mesmo apesar dêsses progressos o comércio não conseguiu emancipar-se da tradicional tutela agrária, não se constituindo, assim, numa atividade econômica independente - na medida em que êle não é apenas o circulador da produção agrária, dependendo, assim, exclusivamente, a intensidade da circulação da maior ou menor produção, e sim, um regulador da produção, sendo esta maior ou menor, conforme a atividade comercial é, mais ou menos, intensa - e capaz de, associado à atividade industrial, adquirir vida própria, tanto no aspecto econômico (erigindo-se em atividade autônoma, isto é, como uma parte característica da economia), quanto no aspecto social (dando origem àquela classe que é, social e econômicamente, a sua

(83). - Fr. Francisco Brandão, op. cit., liv. XVI, cap. XII, apud Schaefer, op. cit., v. I, p. 272.

(84). - Ângelo Ribeiro, op. cit., in "História de Portugal", Ed. Monumental, v. II, p. 295.

(85) . - J. Lúcio Azevedo, Complemento da vida econômica, in "História de Portugal", Ed. Monumental, v. II, p. 427. 
expressão, ou seja a burguesia). Na realidade, muito longe ainda estava o comércio português de poder, por si só, comandar transformações. Fundamentemos a nossa afirmativa, analisando os principais característicos do comércio medieval português.

O comércio, como dissemos, apoiados em várias autoridades, sobretudo em Lúcio Azevedo, estava ligado à terra, constituindo-se, pois, numa atividade, exclusivamente, dela dependente. Temos então, entre outros, um elemento importantíssimo para a compreensão da fraqueza dêsse comércio, e que reside na própria fraqueza da produção agrícola: a de cereais era

$$
\text { "se não deficitária, pelo menos, pouco abundante" (86); }
$$

em 1273 Afonso III proibiu a exportação de pão ou farinha (87); nas côrtes que se reuniram em Santarém (1331) veementes queixas se fizeram sentir contra as autorizações de exportação dadas por Afonso IV (88); e a exportação de cereais que houve desde o tempo de D. Denis ao de D. Fernando, de modo nenhum, significaria um florescimento da agricultura, e sim, simplesmente, o fato de

"exceder a produção às necessidades da população pouco numerosa" (89);

um diploma régio de 1283 aludia à importação de cereais estrangeiros (90); e no preâmbulo da lei das sesmarias, já na época de D. Fernando se declarava que

\footnotetext{
"por todas as partes de nossos Regnos ha desfalicimiento de mantimentos de trigo e de cevada" (91);
}

na riqueza agrícola medieval portuguêsa, o que eqüivale a dizer também na comercial,

v. II, p. 468 .

(86) . - Damião Peres, op. cit., in "Congresso do Mundo Português",

(87). - Idem, ibidem, p. 468.

(88). - Idem, ibidem, p. 468.

(89). - Lúcio Azevedo, O período agrário, in "História de Portugal", Ed. Monumental, v. II, p. 415.

(90) - Damião Peres, op. cit., in "Congresso do Mundo Português", v. II. p. 468 .

(91). - Ord . afons., liv. IV, tit. 81, apud Damião Perés, op. cit., in "Congresso do Mundo Português", v. II, p. 469. 
"a oliveira nunca representou nenhum papel importante"
(92).

Ressentia-se, pois, o comércio de uma maior produção agrícola que, no geral,

"não ultrapassava o consumo nacional" (93).

O que restava então dessa mesma produção agrícola que estivesse em condições de ser colocada no mercado comercial? Apenas vinhos e frutas que - juntamente, com o sal -

"eram os únicos artigos que os mercadores estrangeiros podiam comprar fora de Lisboa, com fins de exportação" (94).

Não nos parece, porém, apesar da questão ainda não estar suficientemente estudada (95), que os referidos artigos, sobretudo as frutas, tivessem trazido grande contribuição para o fomento do comércio medieval português... Outro característico era a não existência de uma política que se preocupasse com saldo da balança comercial, pois, ao invés de se pretender que as exportações superassem as importações, isto é, vender mais do que comprar, o que se fazia, sim, era subordinar a saída de produtos nacionais à entrada de outros estrangeiros, de igual valor, o que quer dizer que primeiro se cuidava de comprar e depois de vender, pelo que se pode deduzir da provisão de Afonso III

(92) . - Alberto Sampaio, As vilas do norte de Portugal, p. 76, apud Damião Perés, op . cit., in "Congresso do Mundo Português", v. II, p. 467; e "nos territórios cuja incorporação na monarquia se efetuara nos tempos mais antigos, tal cultura ou era insignificante, ou não existia". (Gama Barros, História da Administração Pública em Portugal, v. IV, p. 47, apud Damião Peres, idem, ibidem, p. 467); "Cremos, porém, que o consumo interno, fora das regiões produtoras, seria insignificante; na zona setentrional do País, o uso do azeite só com a difusão do cultivo, posterior ao século XIV, se propagaria", (Damião Peres, idem, ibidem, v. II, p. 468).

(93). - Damião Peres, idem, ibidem, v. II, p. 466.

(94). - Idem, ibidem, v. II, p. 466.

(95). - "D'autre part, il est regrettable que l'histoire économique médiévale des pays ibériques - car l'Espagne n'est pas logée à meilleure enseigne - n'occupe pas encore dans l'ensemble des connaissances relatives au passé de l'Europe la place qui lui revient. Il suffit d'ouvrir les grandes histoires économiques généralès dont on dispose actuellement, pour se convaincre que le moyen âge portugais et espagnol y est absolument négligé, ou que l'on sé contente, à ce sujet, de quelques developpements rapides et généralement superficiels". (Charles Verlinden, Le problèm d l'expansion commerciale portugaise au moyen âbe, in "Biblos", Coimbra, Coimbra Editôra Ltda., 1947, v. XXIII, t. II, p. 453-4). 
de 26 de dezembro de 1253 (96). E se acrescentarmos, ainda, o fato de que os produtos que Portugal exportava não eram daqueles que se caracterizavam por possuir valor intrínseco elevado, notando-se, também, que não havia indústria capaz de atender às necessidades internas, compreender-se-á com que facilidade o comércio, para prejuízo da economia portuguêsa, tornou-se deficitário, pois a importação acabou superando a exportação, já que os

"produtos recebidos excediam em valor os que se podiam mandar para fora" e a "diferença preenchia-se em moeda, que os mercadores estrangeiros levavam de Portugal para as suas terras" (97).

Além disso, uma série de restrições e obstáculos não só dificultavam o comércio, como também, atestavam, além da fraqueza, a escassa vocação portuguêsa para êsse tipo de atividade econômica: cada povoação, com seu têrmo, formando uma unidade econômica como que cerrada e, por assim dizer autônoma, como afirma Lúcio Azevedo (98), se constituia num mundo - tão semelhante ao domínio europeu da época do feudalismo - no qual o comércio pouco se fazia neces-

(96). - "Item mando et defendo quod nullus mercator de extra regnum saquet merchandiam de regno nisi duxerit aliam pro illa que se ualeat cum illa" (Port. Mon. Hist., Leg. et Cons., I, p. 194, apud Gama Barros, op . cit., v. V, p. 148, in nota). A respeito dessa provisz̃o assim se expressa Lúcio Azevedo: "Determinação de Afonso III, em 1253, judiciosa, pelas condições da época, em que a escassez era a regra e, pela ausência do crédito e míngua de transportes, os abastecimentos não se realizavam sem dificuldade. Mas não foi isto decerto o que o soberano ponderou, e deve-se atribuir a ordenação ao interêsse fiscal, porque à entrada pagavam dízima as mercadorias, o que não sucedia à saída. A dispensa vinha de se supor que os direitos da exportação pertenciam ao senhor da terra para onde os gêneros iam. Pela importação eqüiivalente cobrava-se a soma relativa ao produto nacional, na aparência isento. Satisfeito o impôsto de entrada, o negociante estrangeiro tirava um "alvará de saca", e podia então embarcar os gêneros adquiridos no reino. Se o negociante era natural, a exportação precedia a importação, mas cumpria-lhe justificar dentro de um ano que a lei fôra cumprida. Quando não provasse ter feito as importações correspondentes, exigia-se-lhe a dízima da mercadorias exportadas. Até aqui o sistema reinante era que as mercadorias saídas se comprassem por mercadorias entradas". (Complemento da vida econômica, in "Ḧistória de Portugal", Ed. Monumental, v. II, p. 423-4). E, a título de curiosidade, é interessante observar-se que, em 1436, a corporaão municipal de Santarém queixava-se a D. Duarte de que no tempo da pesca dos savéis, castelhanos e outros estrangeiros vinham comprar êsse peixe, sem trazerem mercadorias, e "requeria ao soberano que só pudesse levar carga quem tivesse também importado algum carregamento porque dêste modo a povoação seria abastecida de -mantimentos e mercadorias" (Gama Barros, op. cit., v. V, p. 147). (97). - Lúcio Azevedo;" op . cit., in "História de Portugal", Ed. Monumental, v. II, p. 424 . 
sário; e quando de fora vinha, trazido por mercadores ambulantes, o que a localidade não produzia, não se pode dizer que ela conhecesse o verdadeiro, o regular comércio: tratava-se de um comércio, puramente acidental, e que também existiu na Europa, quando a sua econômia era caracterìsticamente agrária (99); a tendência predominante era cada concelho - como se fôsse um mundo fechado - atender apenas o seu próprio interêsse, se é que de fato atendia, separando assim os seus direitos e o seu progresso dos direitos e do progresso dos demais concelhos do país (100): nas Côrtes de 1352, convocadas por Afonso IV, todos os concelhos, com exceção do de Santarém,

"se agravaram de que em vários lugares era proibida aos moradores a venda do pão e vinho da sua lavra a quem fôsse estranho ao concelho, e também não se permitia a exportação por conta própria" (101);

nas Côrtes de 1361, reunidas em Elvas, repetia-se a queixa e se alegava que

"as posturas municipais se guardavam melhor do que a lei geral decretada por D. Afonso IV" (102);

em 1374 o concelho e homens bons de Lisboa manifestavam a D. Fernando o seu descontentamento pela míngua de pão, carne e outros comestiveis,

(98). - Idem, O período construtivo, in "História de Portugal", Ed. Monumental, v. II, p. 402. "Em tôrno da Igreja rural, erigida pelo senhor ou por vizinhos piedosos; dos mosteiros enriquecidos por liberalidades régias e dádivas de particulares, em que se exprimia a fé; do castelo, de onde emanava a lei, e sítio de refúgio em ocasióes de perigo; aglomeravam-se os fogos, formando o centro de uma unidade econômica, que com poucas falhas bastava a si própria". (Idem, Epocas de Portugal Econômico, p. 14).

(99). - Cf. Pirenne, Historia económica y social de la Edad Media,

(100) . - Gama Barros, op. cit., v. V, p. 134. "Êste exclusivismo manifesta-se bem claro nas desigualdades profundas, e não raro odiosas, que se estabeleciam entre os moradores e os estranhos; e era sob a influência dêle que os concelhos regulavam de ordinário, nas suas posturas, as relações comerciais, chegando alguns a proibir a exportação de quaisquer vitualhas. Daí procediam também as peias que estorvavam a cada passo o tráfico interno, e atrofiavam portanto o desenvolvimento da riqueza pública" (idem, ibidem, v. V, p. 134).

(101) . - Idem, ibidem, v. V, p. 134; o rei deliberou no sentido de atender às queixas, mandando que, sem embargo das proibições que existiam, fôssem livres a venda e a exportação do pão ou do vinho $\mathrm{em}$ território português: mas, no dizer de Gama Barros, a "deliberação tomada nas Côrtes de 1352 não produziu resultado, que influisse geralmente no regimem econômico estabelecido pelas corporaçôes municipais" (op. cit., v. V, p. 135).

(102). - Idem, ibidem, v. V, p. 135. 
"porque não os tinha de sua colheita; e não se podiam trazer de fora, porque os concelhos o proibiam por suas posturas" (103);

em 1413 providenciou-se contra a proibição dos concelhos para a saída de pão e carne destinados ao consumo de Lisboa (104); o concelho do Pôrto não permitia que aí se embarcasse trigo, milho e centeio, vindos de fora (105); em algumas partes, também, se proibia a entrada de certos gêneros que a própria localidade produzia (106), e assim por diante. Dessa forma, dificultando-se a exportação,

"recurso que se reputava mais apropriado a cada povoação para conjurar a míngua ou a carestia dos gêneros que nela se produziam" (107),

e também a importação daquilo que era produzido, a unidade econômica portuguêsa, obrigatòriamente cerrada e autárquica, demonstrava, ao mesmo tempo, falta de necessidade da atividade comercial e, paradoxalmente, quando dela carecia, a impossibilidade de realizá-la. Daí se compreender, nesse mundo tão refratário ao comércio, porque não era livre o trânsito de viandantes e mercadorias pelos caminhos que ligavam umas terras a outras e às vêzes, por certos trechos do curso dos rios (108), porque

(103). - Idem, ibidem, v. V, p. 135.

(104). - Idem, ibidem, v. V, p. 136.

(105). - Idem, ibidem, v. V, p. 136.

(106). - Idem, ibidem, v. V, p. 137. Referindo-se, entre outras, a uma dessas localidades, a Guarda, assim se expressa Gama Barros: "Na Guarda e seu têrmo a introdução de vinho de fora constituia uma ofensa ao direito municipal, punida com multa e com a perda da carga e das cavalgaduras que a levavam: exceptuava-se apenas o vizinho que possuia vinhas fora do têrmo, cultivando-as por sua conta; êsse podia trazer o vinho para o concelho, mas só até o Natal, jurando primeiro, quando chegava a festa de São Miguel que era o tempo das vindimas no têrmo, que não mandaria vir outro vinho que não fôsse o seu" (op. cit., v. V, p. 153).

(107). - Idem, ibidem, v. V, p. 152; "Nas Côrtes de Lisboa de 1371 alegava-se que, por efeito da guerra, muitos lugares do país estão sofrenło escassez de pão, gados e mais coisas necessárias à vida; e que se mandam comprar fora o que lhes falta, não o podem obter porque se opõem as defesas, posturas e sizas, que as corporações municipais estabelecem por evitar a exportação" (idem, ibidem, v. V, p. 153): e ao rei - outra prova do quanto era difícil mesmo aquêle comércio acidental - é solicitado "que seja permitido ir comprar mantimentos a concelhos estranhos, levando carta não só do concelho a que pertencer o comprador, atestando a residência, mas também do carregador dando testemunho de que o lugar carece de víveres e não os pode ter da sua produção" (idem, ibidem, v. V, p. 153).

(108). - Cf. Gama Barros, op. cit., v. V, p. 140-8. 
"estradas transitáveis e veículos de transporte não havia" (109),

porque os monarcas nunca se preocuparam com a construção de pontes, visando facilitar ou fomentar o comércio (110), porque, para atender privilégios e privilegiados, proibia-se ao viandante transitar por caminhos mais direto e mais curto, forçando-o a seguir por aquêle outro que mais atendia aos interesses do fisco e não do comércio (111).

À vista do que acabamos de analisar, a constatação da existência das feiras, se nos basearmos na natureza delas, não estará em condições de se constituir em motivo para se acreditar que o comércio conseguiu afirmar-se como uma atividade característica na economia medieval portuguêsa: pelo seu elevado número — durante o reinado de Afonso III, por exemplo,

(109). - Lúcio Azevedo, Epocas de Portugal Econômico, p. 26. "Levavăm-se as cargas a dorso de cavalo, ou muar, ou jumento, quando não às costas de homens, e a cada um dos modos de condução corresponde seu imposto, adequado ao volume" (idem, ibidem, p. 26).

(110). - "Por vêzes encontramos os donativos para pontes; é de crer que pela conveniência do reinante, nas constantes mudanças de residências, e nas operações de guerra, mais que pela dos povos do distrito. E o que se nos depara nas verbas testamentárias e as histórias consignam. Segundo estas, em trezentos anos e mais, as aplicações do tesouro régio, no que chamamos hoje obras de fomento, as pontes excetuadas, cuja erecção e manutenção aliás pertencia aos concelhos, consistem no que teria custado plantar o pinhal de Leiria, e secar alguns paúis, no reinado de D. Denis. Em um e outro caso, seguramente, aproveitando a mão de obra gratúita dos povos vizinhos" (Idem, ịbidem, p. 44).

(111). - "Sucedia isto por exigências dos concelhos, que, disputando a renda a outros da vizinhança, alcançavam para tal fim um decreto real. Conhecem-se alguns casos do tempo de D. Denis. Não faltavam como é natural os protestos, que nem sempre ficavam desatendidos. Em benefício de Gaia, e da povoação contígua, Vila Nova, D. Denis proibira a passagem por certús caminhos. Reclamou a gente do Pôrto, sendo-lhe concedido o livre trânsito por D. Afonso IV, só porém para as pessoas, e com a condição de não levarem carga de espécie alguma. No tempo de D. Fernando já a concessão não era respeitada, e as autoridades do concelho prendiam quem quer que passasse nos lugares vedados, com o pretexto de se não saber se o caminhante era do Pôrto ou de outra terra. Em Coimbra existia a obrigação de passarem os viandantes de uma a outra margem do Mondego através da cidade, e não pelo vaus, acima ou abaixo dela. Mas não só em benefício das povoaçóes se decretava o trânsito forçado. Ao marechal Gonçalo Vaz Coutinho fêz mercê do privilégio D. João I, em favor de uma aldeia do senhorio do agraciado por onde passavam duas estradas, sendo defesa a passagem por outras até então frequientadas. A transgressão importava em pesada multa. Com êstes óbices padecia a comodidade dos habitantes, assim como o tráfico interior, não bastando para lhes tolher os efeitos as providências, aliás salutares, com que, por outro lado, se tentava dar estímulo ao comércio geral" (Idem, Complemento da vida econv̂mica, in "História de Portugal", Ed. Monumental, v. II, p. 421). 


\section{"foram concedidas à maior parte das povoações importan- tes"}

do país (112) - pela freqüência das suas reuniões - ao lado de anuais havia semestrais e, sobretudo mensais, e mesmo quinzenais (113) e semanais (114), (duplo atestado da sua fraqueza econômica), as feiras portuguêsas, ao invés de se assemelharem às verdadeiras feiras medievais européias, surgidas do renascimento do comércio e tendo, por consequiência, sua situação geográfica, naturalmente, determinada pela direção das correntes coreciais (115), verdadeiros pontos

(112). - Herculano, op. cit., v. V, p. 148. "E desde a segunda metade dêsse século (refere-se ao XIII) que a instituição de feiras toma incremento no nosso país, a julgarmos pela freqüência dos diplomas que desde então lhes dizem respeito; e no fim, em 1300, achâmo-las estabelecidas pelo rei em tôdas as províncias, quer seja na mesma carta do fôro que se conferiu à terra, quer seja em diploma especial" (Gama Barros, op. cit., v. V, p. 108). Lúcio Azevedo cita o número de 25 feiras novas criadas nos últimos 45 anos do século XIII só na região de Tras-os-Montes e na Beira, sendo "provável que fora dela e mesmo dentro dos seus confins outras fôssem instituidas" $(O$ período construtivo. in "História de Portugal", Ed. Monumental, v. II, p. 404) .

(113). - Cf. Gama Barros, op. cit., v. V, p. 91-110.

(114). - Antônio Correa, História Econômica de Portugal, Emprêsa Nacional de Publicidade, 1929, v. I, p. 29.

(115). - Pirenne, História económica y social de la Edad Média, p. 102-3. O singular aspecto das feiras medievais portuguêsas, ou seja, a sua não relação com o aumento da atividade comercial e com as grandes correntes do comércio europeu, é referido da seguinte maneira pela historiadora Virginia Rau:

"Em Portugal o quadro era diferente, direi mesmo acanhado e não podemos estender às feiras portuguêsas certas afirmações verdadeiras quanto às feiras francesas ou flamengas. A sua situação geográfica, no extremo-sudoeste da Europa, é suficiente por si só para mostrar que deve ser grande a diferença entre a importância de umas e de outras.

As feiras portuguêsas punham em ligação, quanto muito, a costa de Portugal com o hinterland luso-leonês ou luso-castelhano, a sua esfera de influência era limitada pela posição excêntrica em relação às grandes vias comerciais de então, e pela pequena área territorial que tinham de abastecer. Elas regulavam apenas o movimento de produtos necessários à vida econômica de determinadas regiões, talvez por vêzes de tôda a nação. Além disso multiplicaram-se entre nós tardiamente, numa época em que o grande comércio começava a preferir as rotas marítimas e a centralizar-se em certos portos, desde o mar do Norte ao Mediterrâneo.

Não representávamos nem uma zona de grande produção nem tão pouco de trânsito terrestre, éramos apenas uma zona de consumo e relativamente pouco importante, dado o seu tamanho e a escassez da sua população" (Subsídios para o Estudo das Feiras Medievais Portuguêsas, Lisboa, 1943, p. 14-5).

"Em Portugal houve feiras em vilas, aldeias, póvoas e burgos, como os de Aguiar da Beira, Prado, Alfândega da Fé e Vouzela. Algumas delas foram instituidas em localidades afastadas das principais vias de comunicação, ou arredadas dos grandes centros abastecedores, justamente com o fito de drenar para êsses pontos os produtos que a sua situação desfavorável não lhes permitia alcançarem com facilidade" (Idem, p. 15, in nota). 
de encontros periódicos do comércio internacional, mais se aproximavam de um mercado local - como existiu na Europa carolíngia - ou de um mercado regional (116). Menos foram essas feiras a expressão espontânea de vitalidade econômica, que se manifestaria pela via do comércio, carente de pontos de encôntro, para as trocas necessárias, e sim muito mais o resultado de um artifício da política dos monarcas portuguêses que, por intermédio da instituição econômica - e não da economia, note-se - criavam feiras, como no caso de Afonso III, para

$$
\text { "prover as necessidades das terras sertanejas" (117), }
$$

ou visando.exclusivamente rendimentos de ordem fiscal. Não nasceram elas, portanto, da fôrça do comércio, e sim, foram criadas como consequiência da própria fraqueza comercial: daí o seu localismo e regionalismo, e o seu elevado número e o seu frequiente funcionamento e,

(116). - "Em muitos concelhos notava-se a existência de "açougue" e de "mercado", parecendo-nos possível que por êsse último vocábulo se designasse aí a feira que se reunia um dia certo da semana, o que logo veremos que se verificava em Coimbra em 1269; mas noutros só se encontra referência a "mercado"." (Gama Barros, op. cit., v. V, p. 96). E, para maior esclarecimento, somos tentados a transcrever a seguinte passagem de Pirenne: "En vano se buscará el origen de las ferias (nundinae) en los pequeños mercados locales que, a partir del siglo IX, abundaron cada vez más en toda Europa. Si bien las ferias son posteriores, no existe entre ambos vínculo alguno y sí muchos constrastes. El objeto de los mercados locales consiste, en efecto, en proveer a la alimentación cotidiana de la población que vive en el lugar donde se celebran. Por eso, los mercados son semanales y su radio de atracción es muy limitado; por eso, se concreta su actividad a la compra y venda al menudeo. Las ferias constituyen, al contrario, lugares de reuniones periódicas de los mercadores de profesión. Son centros de intercamios y sobre todo de intercambios al mayoreo que se esfuerzan en traer hacia ellos, fuera de toda consideración local, el mayor número posible de hombres y de productos. Se podria, hasta cierto punto, compararlas con las exposiciones universales, pues no excluyen nada ni a nadie; se puede tener la seguridad de que cualquier individuo, sea cual fuera su patria, cualquier objecto negociable, sea cual fuera su naturaleza, será bien recibido. Por ende, es imposible celebrar anualmente las ferias más de una vez o, quando mucho, más de dos veces en el mismo lugar, puesto que es preciso hacer preparativos considerables.

Es claro que la mayoria de las ferias tuvieron tan solo un radio de acción limitado a una región más o menos extensa. Sólo las ferias de Champaña poseían, en los siglos XII y XIII, un poder de atracción que se impuso a toda Europa. Pero lo que había que indicar es que, en teoria, cada feria está abierta a todo el comercio, como cada puerto marítimo a toda navegación. Entre la feria y el mercado local la oposición no consistia pues, en una simple diferencia de importancia, sino en una diferencia de naturaleza" (História económica y social de la Edad Media, p. 101-2).

(117). - Ângelo Ribeiro, Política de fomento nacional, in "História de Portugal", Ed. Monumental, v. II, p. 280. 
por conseqüência, a sua própria insignificância (118); daí a existência de costumes incompatíveis com a natureza de um verdadeiro regime de feiras, como era o caso da feira quinzenal de Viana, em cuja concessão, outorgada por D. Denis em 1286, se determinava que os moradores do termo não podiam comprar ou vender em outras feiras, sob pena de multa de 60 soldos (119), ou da de Coimbra - quinzenal para Lúcio Azevedo (120), mas mensal para Gama Barros (121) - e que parecia estar na mesma situação que a de Viana (122); daí ainda,

"que em certas localidades se obrigava a ir à feira, sob pena de multa, quem tivesse mantimentos para vender, muitos ou poucos", e em outras "se chegou a estabelecer que uma pessca de cada casa havia. sempre, de ir, tivesse ou não que mercadejar" (123):

estranha maneira de se pretender animar a vida econômica, simplesmente por meio de fatôres que nada tinham de econômicos. Percebe-se através dessa obrigação inadmissível, se de fato houvesse um natural interêsse para as trocas comerciais, não só que as feiras eram pouco frequientadas, como também, obrigando a freqüências às mesmas, os

(118). - A respeito dos mercados locais da época carolíngia Pirenne assim se expressa: "Al parecer, diríase que la abundancia de los mercados está en contradicción con la parálisis comercial de la época, pues, a principio del siglo IX, aquéllos aumentan en forma considerable y se fundan mercados novos, pero su gran número es la mejor prueba de su insignificancia. Sólo la feira de Saint Denys, cerca de Paris (feria del Lendit) atrae, una vez por año, a la vez peregrinos, vendedores y compradores de ocasión. Fuera de ésta, se encuentra únicamente una multitud de pequeños mercados semanales, en donde los campesinos de los alrededores ponen en venta unos cuantos huevos, pollos, unas libras de lana o unas varas de burdo paño tejido en casa. La índole de las transaciones que allí se celebran aparece claramente definida por el hecho de que las ventas se hacen per deneratas, es decir, por cantidades que no exceden el valor de unos quantos denarios.

En resumen, la utilidad de esas pequeñas asembleas consistia en cubrir las necesidades locales de la población de la comarca, y también, quizá, como se observa aún en la actualidad entre los kabileños, en satisfacer el instinto de sociabilidad que es innato en todos los hombres. Era la única distracción que ofrecía una sociedad inmovilizada en el trabajo de la tierra" (História económica y social de la Edade Media, p. 17-8).

(119). - Gama Barros, op. cit., v. V, p. 110.

(120). - O periodo construtivo, in "História de Portugal", Ed. Monumental, v. II, p. 404.

(121). - Op. cit., v. V, p. 110.

(122). - Idem, v. V, p. 110 , in nota.

(123). - Lúcio Azevedo, Epocas de Portugal Econômico, p. 15. 
monarcas tinham em alta conta, antes de mais nada, os seus interêsses fiscais (124).

Quanto ao comércio externo, encontrava-se êle pràticamente nas mãos dos estrangeiros (125): mas a ação dêsses estrangeiros, antes que benéfica para a economia portuguêsa,

"era maléfica, porque empobreciam o País, levando a moeda, vendendo por alto preço seus gêneros e comprando a vil preço os da produção nacional" (125).

Por conseqüência, dêsse comércio quem mais se beneficiava não era Portugal, e sim, os países de origem dos comerciantes. Compreende-se, assim, porque eram êles objeto da animadversão dos portuguêses (127); animadversão essa que ora obrigava os monarcas a endossá-la - para evidente prejuízo do comércio - ora a atenuá-la ou mesmo coibí-la, na sua manifestação, prova do quanto carecia do elemento estrangeiro o comércio português: no reinado de $\mathrm{D}$. Fernando houve representação contra a presença de comerciantes estrangeiros, no país e por lei de 1375 o monarca decretava

"não poderem os estrangeiros fazer operações de comércio, nem direta nem indiretamente senão na cidade de Lisboa, e nos portos do Algarve ou quaisquer outros, onde por costume com-

(124). - "Nas cartas que autorizavam a criação de feira, a disposição relativa à receita fiscal continuava ser: que todos os que vierem a esta feira com suas mercadorias, paguem a mim a minha portagem e todos os meus direitos que deverem pagar dessa feira. Nalgumas cartas, por exemplo a de C.ovilhã, 1260 , e a de Beja, 1261, feiras anuais, diz-șe "que os homens de fora, tanto os vendedores como os compradores, paguem na feira portagem e todos os meus direitos que da mesma feira devessem satisfazer (Chancel. de $D$. Afonso III, liv. I, fol. 46 e $52 \mathrm{v}$ )" (Gama Barros, op cit., v. V, p. 110, in nota). Referindo-se ao fato de Carlos Magno ter proibido aos servos dos seus dominios vagarem pelos mercados, Pirenne acha que tal proibição "demuestra que íban a ellos más bien por diversión que por el afán de ganar dinero" (História económica y social de la Edad Media, p. 18): será que, tornando os monarcas obrigatória a frequiência às feiras portuguêsas, não teriam elas nem a fôrça atraente do entretenimento?

(125) . - Cf. Lúcio Azevedo, Complemento da vida econômica, in " $\mathrm{H}$ istótia de Portugal", Ed. Monumental, v. II, p: 429-30, A circulą̧ão das riquezas, loc. cit., p. 444; Antônio Correa, op. cit., v. I, p. 35.

(126) . - Lúcio Azevedo, Complemento da vida econômica, in "História de Portugal", Ed. Monumental, v. II, p. 425.

(127).. - Idem, ibidem, v. II, p. 424. 
pravam frutas, sal e vinho, o que continuava a ser permitido" (128);

mas em 1395, achando-se na cidade do Pôrto, D. João I recomendava às autoridades

\footnotetext{
"procedimento rigoroso contra quem injuriasse ou maltratasse os mercadores estrangeiros, quer os residentes em Lisboa, quer os que, ocasionalmente, viessem a negócio" (129).
}

Por fim, como veremos logo mais, êsse comércio, dada a sua própria fraqueza econômica, não teve condições, para proporcionar transformações na ordem social. Enquanto isso, vejamos ainda a indústria e a moeda.

Não cabe aqui, pela própria natureza do trabalho, fazer um estudo - como também não o fizemos a respeito do comércio - sôbre a indústria pròpriamente dita de Portugal na Idade Média. Interessa-nos, lògicamente, apenas o seu caráter. São excessivamente escassas as notícias transmitidas pelos documentos referentes à indústria (130); reflexo da própria escassez da atividade industrial. Indústria tal como se costuma entender, atividade de transformação, relacionada com o comércio, constituida em parte característica da economia, não existia em Portugal (131). O que havia, conforme já observamos, apoiados em Lúcio Azevedo - consequêencia do fato da economia portuguêsa ser caracterìsticamente agrária - era uma atividade industrial doméstica, relacionada com a terra (132); adeqüada, portanto, àquêle tipo de economia. E mais uma vez aqui, percebemos a grande distân-

(128). - Idem, ibidem, v. II, p. 425. E a lei punia com severidade os que a tentassem infringir: "O estrangeiro infrator perdia as somas destinadas às compras; o natural, vendedor contra a lei, incorria na pena de morte e confiscação dos bens. Severidade inútil, e que provavelmente não passou nunca do texto legal à prática, visto que as queixas continuaram" (Idem, ibidem, v. II, p. 425$)$.

(129). - Idem, ibidem, v. II, p. 425-6.

(130). - Gama Barros, op. cit., v. IX, p. 215

(131). - "Faltava a indústria que multiplica os produtos, e o comércio que os transporta e oferece" (Lúcio Azevedo, op. cit., in "História de Portugal", Ed. Monumental, v. II, p. 420). Evidentemente, não estamos considerando como fazendo parte da atividade industrial a extração do sal, a pesca, a mineração - atividades de caráter eminentemente extrativo - e muito menos a caça, que Fortunato de Almeida chama de "indústria diretamente relacionada com a alimentação", "que se exercia por tôda parte e tinha por objeto, além das aves, muitos outros animais, como lebres, coelhos, veados, javalis, ursos, zebras e outros" (op. cit., v. I, p. 450).

(132). - Epocas de Portugal Econômico, p. 31. 
cia que separava a indústria portuguêsa doméstica da indústria européia, cada vez mais autônoma. A indústria de panos fornece-nos um exemplo, bastante expressivo: a Europa - estamos ainda no século XII - conhecia a concentração da indústria, nas cidades, pois, a

"afluência dos mercadores nos lugares favoráveis provocou, por sua vez, a dos artesões" (133);

a fabricação dos tecidos, praticada a princípio no campo, emigrou, espontâneamente, para os lugares onde êles poderiam ser vendidos, isto é, as cidades (134); nelas, os tecedores encontravam a lã importada pelos mercadores; os pisoeiros e os tintureiros encontravam o sabão e os materiais corantes (135); a tecelagem, que até então, era uma ocupação reservada às mulheres,

$$
\text { "se converteu numa indústria dos homens" (136); }
$$

os panos de pequenas dimensões - os antigos pallia - foram substituidos por tecidos de dimensões maiores (como os das fábricas da atualidade), a fim de melhor satisfazer as necessidades da exportação (137); enfim, como parece ter ficado evidente, uma

"verdadeira revolução" acompanhou "esta transformação da indústria rural em indústria urbana" (138).

Em Portugal não houve concentração da indústria de panos nas cidades, pois que, não houve também concentração comercial e assim aquela indústria - contràriamente à européia que já se revestia de um caráter urbano - continuou com o seu caráter rural: era uma humilde (139) indústria doméstica (140), destinada a atender às ne-

(133). - Pirenne, História económica y social de la Edad Media, p. 49.

(134). - Idem, ibidem, p. 50.

(135). - Idem, ibidem, p. 50.

(136). - Idem, ibidem, p. 50.

(137). - Idem, ibidem, p. 50. E também pode-se "suponer con fundamento que se había producido, en la misma época, un cambio en el oficio de los tejedores, aunque no fuese más que el de permitir el arrollamiento en el enjulho del estambre que medía de 20 a 60 varas" (idem, ibidem, p. 50).

(138). - Idem, ibidem, p. 50.

(139). - Lúcio Azevedo, Epocas de Portugal Econômico, p. 24.

(140) . - Idem, Complemento da vida econômica, in "História de Portugal", Ed. Monumental, v. II, 431. Mesmo no século XV essa indústria conservava o seu caráter puramente doméstico; "São um tanto menos escassas as notícias acerca da indústria de que estamos tratando, em relação ao século XV. As Côrtes de Lisboa de 1439, há pouco citadas, dão testemunho da indústria doméstica de panos de lã. É num capítulo dos especiais apresentados pela vila de 
cessidades locais; monopolizada pelas mulheres, donas ou servas (141); a exportação dos panos de côr (142), por carta régia de 1254 ou 1255 era proibida (143), prova de que sua produção mal dava para satisfazer às exigências nacionais; daí a necessidade de importações (144); nenhum progresso técnico: era uma indústria grosseira (145). As alfaias agrícolas, semelhantemente à tecelagem, se fabricavam

"na área da casa senhorial e seus domínios" (146).

Enfim, com o seu caráter doméstico - que não desaparecia, mesmo, quando os seus produtos apareciam nos mercados locais (147), com o seu número minguado de indivíduos, no exercício de profissão especializada, com a sua impotência, não só para proporcionar transformações de ordem econômica, como também transformações de ordem social, acreditamos ser adeqüada a designação de bisonha que um historiador reserva à indústria portuguêsa na Idade Média (148) .

No que se refere à moeda, a economia portuguêsa não foi, caracterìsticamente, monetária, aproximando-se em grande parte, nesse aspecto, da economia européia, anterior ao renascimento do comércio. A economia da Europa, antes do renascimento do comércio do século XII, sòmente pode ser chamada de economia natural, no sentido de que a moeda teve uma circulação e uma importância muito limitadas, tanto assim que a organização dominial chegou a prescindir dela (149). $\mathrm{O}$ que, absolutamente, não quer dizer que ela deixou de ser o instrumento normal das transações comerciais (150), não havendo dúvida

Leiria. Pede-se nêle que não haja dízima do pano de lã que alguem fizer para o seu vestir ou de seus servidores, pois é para o gasto de sua casa. Tem deferimento a pretensão, mas se for para vender pagará a dízima" (Gama Barros, op. cit., v. IX, p. 217).

(141). - Lúcio Azevedo, op. cit., in "História de Portugal", Ed. Monumental, v. II, p. 431 .

(142). - "A fórmula "panos de côr", na sua significação mais lata, designava, segundo parece, todos que não eram de linho, fôssem ou não de trabalho nacional" (Gama Barros, op cit., v. IX, p. 216, in nota).

(143). - Gama Barros, op. cit., v. IX, p. 216.

(144) - Lúcio Azevedo, Complemento da vida econômica, in "História de Portugal", Ed. Monumental, v. II, 420.

(145). - Fortunato de Almeida, op. cit., v. I, p. 454.

(146). - Idem, ibidem, v. I, p. 431.

(147). - Saraiva, op. cit., v. I, p. 39.

(148) . - Lúcio Azevedo, op . cit.., in "História de Portugal", Ed. Monumental, v. II, p. 423 .

(149) . - Pirenne, História económica y social de la Edad Media p. 111.

(150). - "Si se recurre al trueque, es tan sólo por motivo de conveniencia o de práctica accidental, como a un sucedáneo, pero no como a un sustituto de la moneda metálica. Los textos no dejan lugar a dudas a este respecto. Dal 
que, sempre que existiu intercâmbio comercial, existiu intercâmbio monetário (151): mas, porque era escassa a circulação de mercadorias naquela época, escasșa foi também a circulação monetária (152); as prestações econômicas eram pagas sob a forma de produtos naturais e de jornadas de trabalho, sendo insignificante o que era acrescentado sob a forma monetária (153). Tudo isto, no entanto, como já vimos, irá mudar, completamente, com o renascimento do comércio do século XII, surgindo um nôvo tipo de economia, a monetária, em substituição à "natural". Em Portugal, contudo, as coisas parece que não se passaram da mesma maneira. Na economia portuguêsa até o século XIII, ou seja, até o nascimento da Universidade, podemos distinguir duas etapas distintas: uma primeira etapa de economia natural e uma segunda de transição - de transição note-se bem - de economia natural para economia monetária. Até o século XII predominava a economia natural (154): o pão - sendo a principal necessidade e a principal riqueza, riqueza imutável que ninguém rejeitava - era a medida dos valores, o que mais estava adeqüado, para exercer a função de moeda (155); às vêzes a troca era direta, objeto por objeto, sem intromissão de um terceiro que servisse de unidade (156); algumas vêzes

siglo IX hasta al XII, no se ve que los precios se expresen en forma alguna que no sea la de la moneda, nin aunque prevean el caso en que cualesquiera objetos pudieron darse en pago en lugar de aquélla. Basta leer las capitulaires para comprobar que las pequeñas transacciones que se celebran en los mercados locales, donde los intercambios en especies serían, sin embargo, tan fáciles, se hacen por deneratas. Es más: la aceptación forzosa de la moneda se promulgara formalmente en dichos mercados. Es sabido, por otra parte, que después de la época carolíngia, quando un soberano concedía el permiso de estabelecer un mercado, de costumbre otorgaba al mismo tiempo al concesionario el derecho de acuñar moneda y esta coincidencia demuestra, sin lugar a dudas, que la moneda sirvió normalmente de medida de los valores y de instrumento de las compras" (Pirenne, op. cit., p. 109).

(151). - Idem, ibidem, p. 109.

(152). - Idem, ibidem, p. 110 .

(153). - Idem, ibidem, p. 110.

(154). - Lúcio Azevedo, Epocas de Portugal Econômico, p. 40.

(155). - Lúcio Azevedo, A circulação das riquezas, in "História de Portugal", Ed. Monumental, v. II, p. 434. "Frequientemente tomava-se o módio, medida de cereais, como representante dos outros valores, como unidade para a comparação dêstes entre si. Tantos côvados de tela avaliados em tantos módios trocavam-se por um cavalo, por uma armadura, por tantos hastins de terra. Assim no mais. A dificuldade dêste sistema de permutações, as inconveniências da falta de uma unidade invariável para comprar os valores são óbvias. Só a necessidade pode dar razão dêsse estado de coisas. A frequiência, portanto, de semelhantes transações, de que existem milhares de documentos, demonstra a raridade do dinheiro" (Herculano, op. cit., v. V, p. 150).

(156). - Lúcio Azevedo, op. cit., v. II, p. 434. 
também - embora muito raramente (157) - as moedas apareciam entre as coisas dadas em pagamento (158): mas o seu aparecimento, no dizer de Lúcio Azevedo, se dava, apenas sob a forma de riqueza acumulada e não como instrumento usual das permutas, pois o numerário entrava nas operações na qualidade de mercadoria preciosa, sob forma de riqueza imobilizada (159); e os

"tributos estabelecidos por uso, por transmissões do domínio útil dá Corôa, quer singulares quer coletivos, ou pelas cartas de municípios chamadas forais, correspondiam exatamente a esta situação econômica" (160).

A pouco e pouco, sobretudo a partir da segunda metade do século XIII - época em que, como vimos, na parte anterior dêste capítulo, houve acréscimo das relações comerciais com o exterior dá-se o aumento da circulação monetária (161); e, gradualmente, as prestações em gênero impostas à terra e os encargos de serviço pessoal foram se convertendo em obrigações pecuniárias (162). Vai assim a economia portuguêsa adquirindo um caráter de economia monetária. Não se pode dizer, porém, que, com a aquisição dêsse nôvo caráter, o que surgiu foi uma verdadeira economia monetária, pois permaneceram os característicos da economia natural: o que se deu, quanto muito, foi uma transição de um tipo de economia para outro, coexistindo simbiòticamente os dois. Realmente: tendo

"a agricultura por principal indústria, e determinado por ela o movimento comercial, o acréscimo da riqueza e o maior giro dos metais amoedados deviam ser um fato gradual e vagaroso" (163);

a variedade monetária, afirma Lúcio Azevedo, não era uma decorrência de fatôres econômicos, e sim, o resultado do modo de aquisição

(157). - "As produções do solo, os artefatos grosseiros da nascente indústria, os animais domésticos, os produtos da caça e da pesca, o trabalho manual, tudo servia de moeda. A contribuição nesta espécie apenas figura com uma pequena quota e falta absolutamente na máxima parte dos contratos particulares" (Herculano, op. cit., v. V, p. 150).

(158). - Gama Barros, op. cit., v. V, p. 31 e seg.

(159). - Op. cit., in "História de Portugal", Ed. Monumental, v. II, p. 434-5.

(160). - Herculano, op. cit., v. V, p. 150

(161). - Gama Barros, op. cit., v. V, p. 38.

(162). - Lúcio Azevedo, O período agrário, in "História de Portugal", Ed. Monumental, v. II, p. 410 e seg.; Fortunato de Almeida, op. cit., v. I, p. 419

(163). - Herculano, op. cit., v. V, p. 151-2. 
primitiva: despojos de guerra, produto dos fossados e periódicas invasões, em território inimigo (164); a função essencial da moeda instrumento de troca - era muito limitada e mesmo insignificante (165): sua aplicação mais comum era nos tributos e a não ser por ocasião das feiras, raramente, haveria a oportunidade para se empregar a moeda em atos de comércio (166); mas muitos impostos continuaram a ser pagos em gêneros, ou parte em gêneros e parte em moeda, ou ainda sob a forma de serviços corporais (167). Dessa forma, a economia portuguêsa se apresentava híbrida, isto é, parte monetária parte natural ou, se preferirmos, monetário-natural. Esse hibridismo não passou de um reflexo da própria fraqueza do comércio português. Se raciocinarmos de acôrdo com Pirenne, a circulação monetária regrediu em correspondência com a regressão da circulação das mercadorias, assim como ela progrediu na mesma proporção em que progrediu o comércio (168). Explica-se então porque com o renascimento do comércio do século XII a circulação monetária

$$
\text { "que nunca havia desaparecido" (169), }
$$

progrediu, numa proporção tal, que a economia européia se tornou caracterìsticamente monetária. Em Portugal, no entanto, seu comércio não teve aquêle poder transformador: anunciou o futuro, a economia monetária, mas não pôde fazê-lo sem deixar de continuar comprometido com a economia natural, o passado.

(164). - "Pois, sem comércio externo de alguma importância, como haviam de transformar-se em metais preciosos, que se não extraiam no País, os produtos da terra?" ( $A$ circulação das riquezas, in "História de Portugal", Ed. Monumental, v. II, p. 436).

(165). - Lúcio Azevedo, op. cit., in "História de Portugal", Ed. Monumental, v. II, p. 436. "As compras e vendas no sentido de obter produtos por dinheiro e dinheiro por produtos, poucas vezes se realizavam no tráfico de todos os dias" (idem, ibidem, v. II, p. 436).

(166). - Idem, ibidem, v. II, p. 436.

(167). - Idem, O período agrário, v. II, p. 409 e seg. "Entretanto, ainda no fim do reinado de Afonso III, certos direitos, acaso por importarem em somas relativamente consideráveis, de que não podiam dispor os indivíduos obrigados ao pagamento, se arrecadavam em mercadorias. Tal a dízima dos panos estrangeiros; se não sēmpre e em tôda parte muitas vêzes. E sucedia que as fazendas recebidas utilizava-as o soberano em seus próprios pagamentos. Os criados de D. Denis, quando, herdeiro da Corôa, se the estabeleceu casa, recebiam em panos a preços determinados, soldadas e gratificações (Idem, Épocus de Portugal Econômico, p. 40-1.

(168). - História económica y social de la Edad Media, p. 85-6, 110. 
Com uma economia nas condições em que acabamos de apresentá-la - comércio fraco, além de dependente da terra; indústria doméstica e rudimentar, circulação monetária escassa - e evidenciando, por conseqüência, aspectos anacrônicos, se comparada com a revolucionária economia européia, não é de estranhar que a vida social portuguêsa, na Idade Média não tenha se caracterizado por transformações de vulto. Do mesmo modo que não houve uma revolução econômica, não houve também uma revolução social. Socialmente, em perfeita correspondência com o ruralismo da sua economia, Portugal se caracterizava, por ser uma vasta associação de lavradores. E seu comércio, sua indústria e sua moeda não tiveram a fôrça necessária, para modificá-la, pois não conseguiram dar origem aos tipos sociais caracteristicamente representativos daquelas atividades. $O$ verdadeiro comerciante, isto é, o mercador de profissão, vivendo exclusivamente do comércio, não existia (170): o próprio produtor era o negociante (171); intermediário entre produtor e consumidor, ou seja, o comerciante, não havia (172). As vêzes, em certas regiões, surgia um tipo de comerciante, o comerciante nômade (173): exprimia êle, no entanto, antes de mais nada, o atrazo e o primitivismo do comércio português. A insignificância do elemento industrial era um reflexo da insignificância da própria indústria: seria minguado o número de indivíduos, no exercício de profissão especializada (174); a importância dêsses mesmos indivíduos - chamemo-los de mesteirais - até o século XIV era pequena (175); incontestável era a inferioridade, como elemento político, do industrial com relação ao agricultor, frequientemente, manifestada nas côrtes, com os pedidos de restrição para a liberdade de trabalho (176); nos concelhos

(169). - Pirenne, op. cit., p. 85.

(170). - Lúcio Azevedo, Complemento da vida econômica, in "História de Portugal", Ed. Monumental, v. II, p. 420.

(171) . - Idem, ibidem, v. II, p. 420.

(172). - Idem, O periodo construtivo, in "História de Portugal", Ed. Monumental, v. II, p. 400.

(173). - "De terra em terra, de feira em feira, de casal a castelo, o mercador supria das coisas precisas o habitante sedentário. Não se cuide em negócio de alto valor. Nesta época em que não existia o crédito, todo o haver do negociante caminhava com êle, em poucas cavalgaduras, único meio de transporte para fazendas e pessoas" (Idem, Complemento da vida econômica, loc. cit., p. 420). Grandes comerciantes, em relações com os países estrangeiros, também não houve, mesmo porque o comércio externo, como já vímos, era geralmente praticado por estrangeiros, "e quando por nacionais, na pequena escala que seus meios, na ausência do crédito, permitiam" (Idem, $A$ circulação das riquezas., loc. cit., p. 444).

(174). - Idem, Complemento da vida econômica, in "História de Portugal", Ed. Monumental, v. II, p. 431.

(175). - Gama Barros, op. cit., v. III, p. 87.

(176). - Idem, ibidem, v. III, p. 87. 
"e esta circunstância mostra com evidência a pouca importância que tinham geralmente os mesteirais, e por conseguinte manifesta igualmente o atraso das indústrias" (177) -

a tendência era dar proteção exclusivamente ao trabalho rural (178); também, porque os

$$
\begin{aligned}
& \text { "monumentos legislativos e os Costumes não ministram prova } \\
& \text { para asseverar a afirmativa" (179), }
\end{aligned}
$$

pode-se duvidar - como o faz Gama Barros - de que em Portugal, anteriormente ao século XVI, tenham existido as corporações das artes e ofícios (180), e que tanto caracterizaram a economia urbana da Europa medieval. Também não se constituiu, socialmente, um grupo originário de uma atividade, baseada no crédito e no comércio do dinheiro, pois esta faceta da economia monetária, apenas primária, irregularmente se esboçou na economia portuguêsa. É bem verdade que havia os judeus, parcela de uma população de lavradores, que rejeitava os trabalhos da terra (181): conservavam êles o monopólio do comércio do dinheiro (182), na qualidade de banqueiros dos indivíduos de medíocres recursos e dos pequenos proprietários (183). Mas constituiam êles uma

"turba parasita de usurários e exatores" (184);

formavam no organismo social uma excrescência (185); não contribuiram sensìvelmente, para o progresso econômico da nação (186); e o monopólio do comércio do dinheiro que conservavam

"numa época em que a banca internacional estava já largamente desenvolvida na França, Flandres e Itália" (187)

(177). - Idem, ibidem, v. III, p. 87.

(178). - Idem, ibidem, v. III, p. 87.

(179). - Idem, ibidem, v. III, p. 88.

(180). - Idem, ibidem, v. III, p. 88.

(181). - Lúcio Azevedo, $A$ circulaşão das riquezas, in "História de Portugal", Ed. Monumental, v. II, p. 443.

(182). - Antônio Saraiva, op. cit., v. I, p. 39.

(183): - Lúcio Azevedo, op. cit., in "História de Portugal", Ed. Monumental, v. II, p. 443 .

(184). - Idem, ibidem, v. II, p. 444.

(185). - Idem, ibidem, v. II, p. 444.

(186). - Idem, ibidem, v. II, p. 444.

(187) . - Antônio Saraiva, op. cit., v. I, p. 39. 
era antes de mais nada um sintoma do atraso da economia monetária portuguêsa, sobretudo se comparada com aquela das regiões econômicamente mais desenvolvidas da Europa (188).

Em razão do que acabamos de expor, podemos e devemos concluir que, na sociedade medieval portuguêsa, especialmente, antes da fundação da Universidade, talvez não tivesse existido a burguesia (189). A não existência dessa classe se constituiria numa das peculiaridades da sociedade medieval portuguêsa, assim como na história -européia, contràriamente, a existência da burguesia foi uma das peculiaridades da sua sociedade. Na Europa, saida de uma revolução econômica, que propiciou uma revolução social, surgiu uma classe, a burguesia, cuja atuação, revolucionária também, impressiona antes de mais nada pela multiplicidade dos seus aspectos, inclusive os de ordem cultural. Já fizemos referência a essa questão no capítulo anteriur dêste trabalho, mas não será demasiado insistir que: a burguesia européia se erigiu numa classe distinta (190); criou o seu próprio munöi, o das cidades, em contraste com o antigo mundo, o do campo (191j: foi um agente de progresso social e de civilização (192); o seu aparecimento, juntamente, com o progresso da vida urbana, se constituiu no acontecimento que mais importância teve para o desenvolvimento ulterior da cultura européia (193). Pois bem, em Portugal não teria existido essa classe, que foi, a um só tempo, um poderoso elemento econômico, social, político e cultural. Seus mercadores, por exemplo, longe estiveram de ser a parte mais numerosa e mais característica da classe média portuguêsa (194), e o

(188). - Idem, ibidem, v. I, p. 39. A êste respeito, aliás, Pirenne se expressa da seguinte maneira: "En relación con el florecimiento y la ubicuidad del crédito de los italianos, el de los judios parece deleznable. De seguro, se ha exagerado mucho el papel que desempeñaron en la Edad Media. Es curioso observar, para apreciar em su justo valor dicho papel que, cuanto más adelantado está un país desde el punto de vista económico, menos prestamistas judíos hay en él" (História económica y social de la Edad Media, p. 135).

(189). - Mesmo na época das descobertas não teria existido uma verdadeira burguesia em Portugal. A essa questão assim se refere Lúcio Azevedo: "Não havia nêsse tempo uma burguesia nacional, numerosa e rica, que tivesse posses para entrar nestas emprêsas dispendiosas, de que os acidentes de guerra e mar faziam o lucro incerto. Em compensação encontramos na aventura pessoas da nobreza". (Portugal potência mercantil, in "História de Portugal", Ed. Monumental, v. III, p. 638).

(190). - Halphen, L'Essor de l'Europe, p. 94.

(191). - Pirenne, Histoire de l'Europe, p. 163.

(192). - Idem, ibidem, p. 163.

(193) . - Nordström, op. cit., p. 50-1.

(194). - Antônio Saraiva, op. cit., v. I, p. 60. 
"que a distingue relativamente à classe corresprndente em França, Itália e Flandres, é ser uma classe média rural e não, como naqueles países, uma burguesia urbana" (195).

Assim, enquanto que na Europa a burguesia urbana, se levarmos, sobretudo, em conta a sua origem, era o que havia de mais representativo, daquilo que poderíamos chamar o povo, em Portugal as classes superiores dêsse mesmo povo eram os cavaleiros e os peões (196). Mas os cavaleiros - que Gama Barros chegou a chamar de representantes da aristocracia do povo (197) — e os peões constituiam classes caracteristicamente rurais. E precisamente aqui que a sociedade portuguêsa se revelaria, particularmente anacrônica: com o aparecimento das cidades e a constituição da burguesia, a sociedade européia se completa e a trindade clero, nobreza, burguesia dirigirá os destinos da Europa até o fim do Antigo Regime (198); no entanto, na sociedade portuguêsa, faltaria um dos elementos da trindade, a burguesia; ao invés de têrmos - como sucedeu, na Europa - clero, nobreza e burguesia de um lado e o povo do outro, o que teríamos na sociedade portuguêsa seria clero, nobreza e povo. Faltaria, portanto, na fórmula da sociedade portuguêsa, o mais importante dos elementos sociais. Nesse sentido é que ela era uma sociedade inacabada, incompleta, anacrônica. Eis porque, é necessária muita cautela, quando se analisa a sociedade medieval portuguêsa: insistir na existência da burguesia, como fazem certos historiadores, seria incorrer, no maior dos erros históricos, qual seja o de pretender dar existência àquilo que não teria existido, isto é, na negação da própria História. Na realidade, a "burguesia" medieval portuguêsa não seria um fato histórico, e sim um "fato" historiográfico. Não teria existência temporal, e sim apenas "existência" livresca .

A fraqueza da vida urbana completa o quadro do agrarismo medieval português. Com uma economia tìpicamente rural e sendo, socialmente, por consequiência, uma associação vasta de lavradores, dificilmente se pode pretender encontrar em Portugal um renascimento de caráter urbano. Antes o contrário (199), tal era a fraqueza da

(195). - Idem, ibidem, v. I, p. 60.

(196). - Gama Barros, op. cit., v. III, p. 46.

(197). - Idem, ibidem, v. III, p. 47.

(198) . - Pirenne, Histoire de l'Europe, p. 166.

(199). - "La villa medieval es, por lo tanto, esencialmente una creación de la burguesia. Existe sólo para los burgueses y gracias a ellos. En su interés propio y excluivo, crearon la intitucione y organizaron la economía. Ahora bien, e evidente que el desarollo más o menos amplio de dicha economía dependió del hecho de que la población en favor de la cual funcionaba fuera más o menos numerosa y participara con mayor o menor actividad en el movimiento comercial e industrial" (Pirenne, Historia económica y social de la Edad Media, p. 171). 
vida urbana portuguêsa, resultado do domínio quase que total do agrarismo. Através de vários aspectos manifestava-se a referida fraqueza urbana. Muitas das aglomerações urbanas nasciam sem nenhuma espontâneidade, pois ao invés de surgirem como um resultado da atividade econômica, surgiam sim como consequiência do interêsse fiscal dos monarcas (200), portanto do interêsse financeiro. Algumas dessas aglomerações, concelhos se se preferir, eram de insignificância a mais insignificante que se possa imaginar (201). Poucos eram os casos de comunas urbanas em Portugal, mesmo porque os concelhos diferentemente das comunas italianas, francesas e flamengas, tìpicamente urbanas e geradas pelo renascimento do comércio - não passavam de comunidades agrárias (202). Além

"de Lisboa e Pôrto não deve ter havido em Portugal grandes núcleos urbanos" (203).

Mesmo nas mais consideráveis aglomerações urbanas predominava a feição agrícola, como fàcilmente se pode depreender da seguinte passagem de J. Lúcio Azevedo:

(200) . - J. Lúcio Azevedo, Epocas de Portugal Econômico, p. 17; "A criação de Vila Nova de Cerveira, em $1217(?)$, por D. Denis, assaz nos elucida sôbre o modo porque se fundavam as vilas. O monarca dirige-se em carta aos seus encarregados fiscais na comarca - "A vós João Soares, meu Sacador além Douro, e a Gil Martins meu Escrivão, e a Estevão Eanes, meu Almoxarife, e a Estevão Raimundo, meu Escrivão de Valença" - participando-lhes o intento de criar uma povoação a par do Castelo de Cerveira; incumbe-lhes buscarem homens dispostos a estabelecerem-se lá; e assenta em conceder para o eîeito vinte casais, que possui no local, e uma igreja. Os novos povoadores hão-de ser cem, ficando obrigados ao foro de 200 libras por ano, e mais em dinheiro o equivalente ao que os casais rendiam" (Idem, ibidem, p. 16-7).

(201) . - "Dos agrupamentos à roda da pequena igreja, do mosteiro ou do castelo, tinham brotado os concelhos. Tão insignificantes alguns, e tal em certos sítios a escassez de gente, que houve foral concedido a um grupo de só dez famílias - assim o de Soverosa em 1196 —; de quatro, de três, e até de uma só: os de Antela, Souto e Fonsim, êste último em 1255. Favoráveis as condições locais à agricultura, o núcleo engrossava com adventícios: gente de passagem, refugiados, obreiros de ofícios, mercadores, visitantes acidentais que acabavam por fixar-se. Outros, pelo contrário, não possuiam condições de vitalidade, e tiveram de ser anexados a algum mais próspero. Sucedia às vêzes ser a sede do concelho lugar deserto ou quase, derramando-se a população pelas aldeias e freguesias rurais. Em 1572 , no censo a que mandou proceder d. João III, verificou-se haver, por exemplo, em Trás-os-Montes, no concelho de Teixeira, dois moradores no lugar, e quarenta e seis outros em suas residências rústicas. No de Penaguião, com cinco freguesias, na sede ninguém morava. Erguia-se no ermo a casa das audiências, e em frente o lugar da forca, com o rude pelourinho, emblema da autonomia local" (Idem, ibidem, p. 16).

(202). - Saraiva, op. cit., v. I, p. 37.

(203). - Idem, ibidem, v. I, p. 60; cf. também J. Lúcio Azevedo, $O$ periodo construtivo, in "História de Portugal", Ed. Monumental, v. II, p. 401. 
"Além disso o grosso da população compunhá-se, na realidade de agricultores, que tinham nos arrabaldes suas hortas e terras de pão. Os mesmos homens de ofícios amanhavam, nos intervalos do trabalho profissional, as suas leiras. Outro tanto se vê, ainda ago$\mathrm{ra}$, nas povoações rurais, onde os proventos do mister não bastam para as necessidades do obreiro. Dentro dos limites do povoado largas superfícies pertenciam à agricultura. Assim era nas duas principais cidades do reino, Pôrto e Lisboa, onde na primeira, e já no século XV, o convento de Santa Clara foi construido, em terras de lavoura, e em terrenos de hortas se abriu a rua das Flôres, tudo no interior da cêrca; em Lisboa, onde D. Manuel mandou destruir os olivais, tão abundantes que davam à metrópole um aspecto rústico de que o soberano se humilhava. Que iulgaremos das povoações menos importantes e de tempos anteriores? Em Braga, cabeça de distrito romano e capital da monarquia dos suevos, existiam bosques de carvalhos e castanheiros, no sítio em que o arcebispo, no século $\mathrm{XV}$, traçou duas ruas principais, a do Souto e a Rua Nova. Também neste século a Câmara de Coimbra proibe largarem-se bois a pasto, nos olivais, vinhas e hortas, de que havia quantidade no recinto urbano. Nas côrtes de 1481 queixam-se os povos de Santarém de andarem, à solta, na vila, varas de porcos, que fossavam nos adros, desenterravam os cadáveres, e enchiam de imundícies o povoado. $E$ assim, seria por tôda a parte, como ainda se vê nas aldeolas e vilotas atrasadas" (204).

Não havia uma capital fixa para o Reino, pois era

"mais pròpriamente o centro da administração a cidade, vila ou lugar em que o soberano se encontrava, sendo para aí que haviam de afluir todos os negócios, cuja resolução dependia do rei, ou dos ministros e tribunais que o acompanhavam, nas suas repetidas jornadas pelo país" (205):

de uma maneira geral Guimarães, Coimbra, Santarém e Lisboa disputavam as preferências dos monarcas; foi sòmente nos fins do século

(204) - - Op. cit., in "História de Portugal", Ed. Monumental, v. II, p. 401-2. E Gama Barros referindo-se a um foral do tempo de D. Fernando assim se refere a respeito de Lisboa: "O que predomina em todo o foral são produtos agrícolas, gados e objetos que têm relação com a cultura da terra. A leitura dêste documento deixa a impressão de que se trata aí da capital de um país, que é principalmente lavrador" (apud J. Lúcio Azevedo, Complemento da vıda econômica, in "História de Portugal", Ed. Monumental, v. II, p. 420).

(205). - Gama Barros, op. cit., v. III, p. 199. 
XIV com D. João I que Lisboa acabou sendo reconhecida como a verdadeira capital (206). Até essa época, portanto, era nômade o monarca português - e

"é possivel que a necessidade de se aproximar dos celeiros, onde as substâncias se acumulavam, mais vêzes fôsse a causa das jornadas do soberano, que o zêlo de administrar a justiça, com que a imposição do tributo do jantar ou colheita se justificava" (207);

e nômade era também a administração do seu Estado. Eis aqui mais uma prova da debilidade da vida urbana portuguêsa, pois nos Estados europeus - já vimos - o nomadismo da administração correspondeu à época do predomínio absoluto do agrarismo; e foi com o renascimento urbano, mas sòmente com êle, que a administração se sedentarizou. $\mathrm{E}$ eis aqui também, e por consequiência, mais uma outra prova do arcaismo social português.

Foi talvez pensando na precariedade da vida urbana portuguêsa que Costa Lobo, embora referindo-se ao fim da Idade Média, afirmou:

"Nos princípios do século XV, Portugal pode descrever-se como um vasto matagal, entressachado, afora algumas cidades $\mathrm{e}$ vilas, de pequenas povoações, circundadas de breves arroteas" (208).

Mas se êsse era o aspecto do país no século XV é-nos lícito acreditar, juntamente com J. Lúcio Azevedo, que há dois séculos atrás êle seria muito mais pronunciadamente agrário, para não dizer agreste. como

"atesta a quantidade de animais silvestres, cuja abundância tinha parte notável na vida econômica da nação" (209).

E Herculano, apesar das restrições de Gama Barros (210), dá-nos uma impressionante idéia do que era Portugal nos séculos XII e XIII:

(206). - Idem, ibidem, v. III, p. 200.

(207). - J. Lúcio Azevedo, $O$ periodo agrário, in "História de Portugal", Ed. Monumental, v. II, p. 413.

(208). - História da Sociedade em Portugal no século $X V$, Lisboa, Imprensa Nacional, 1901, p. 77.

(209). - Epocas de Portugal Econômico, p. 24.

(210). - Op. cit., v. V, p. 17. 
"Quando nos forais dos séculos XII e XIII se vão seguindo aquelas extensas demarcações dos têrmos dos concelhos (principalmente dos situados no sul do reino) que se dilatam por muitas léguas em faixas tortuosas e enredadas; quando vemos frequientes vêzes indicarem-se aí, como balisas, apenas a penedia dentada que orla o espinhaço das serras, o carvalho que nasceu insulado, a "velha" estrada mourisca, a pedra que sobressai entre as outras pela sua cor, a torrente que se despenha pelas ladeiras, 0 rio que passa entre as brenhas, o vilar "antigo" a que já se não sabe o nome, porque não há lá quem o diga, e jamais o casal, a courela, a habitação humana, quase que sentimos aquêle zumbido que $o$ excesso do silêncio parece produzir, e como que nos oprime o espírito um sentimento indefinível de solidão. Tal era o país" (211).

Podemos agora então afirmar que não houve renascimento urbano em Portugal. Difícil, portanto, senão impossível, encontrar condições sociais para o estabelecimento da Universidade. Poder-se-á dizer o mesmo com relação às condições culturais?

\section{(Continua) .}

(211). - Historia de Portugal, v. III, p. 146-7. 